\title{
PRODUCTION AND PROPERTIES OF BORDETELLA PERTUSSIS HEAT-LABILE TOXIN
}

\author{
I. LIVEY* AND A. C. WARDLAW
}

\section{Department of Microbiology, University of Glasgow, Glasgow G11 6NU}

\begin{abstract}
Summary. Twelve selected strains of Bordetella pertussis were compared quantitatively for their ability to produce heat-labile toxin (HLT); all proved to be active producers, with only a three-fold range between the highest and the lowest. Bordet-Gengou agar, charcoal agar, modified Hornibrook medium and Stainer and Schölte (12G) medium differed little in their ability to support toxin production by three $B$. pertussis strains. However, cells grown on the solid media for $24 \mathrm{~h}$ were slightly more toxic than their counterparts grown for $72 \mathrm{~h}$ whereas in the liquid media the opposite was true. The concentration of iron in the medium did not influence HLT production, but high concentrations of nicotinic acid significantly reduced the HLT content of the cells. Crude preparations of toxin underwent only a $10 \%$ loss of toxicity per annum at $-20^{\circ} \mathrm{C}$ and were stable for up to 2 weeks at $4^{\circ} \mathrm{C}$. At $37^{\circ} \mathrm{C}$, toxicity was lost within a few days. The toxin was partially purified by a series of mild procedures and had a mol. wt by gel filtration of $89000 \pm 10 \%$. HLT was toxoided by treatment with formaldehyde to give a product which was immunogenic in rabbits but not in mice. Because anti-HLT could be absorbed out of the rabbit antisera by treatment with intact $B$. pertussis, it was concluded that some of the HLT in the bacteria is surface-exposed even though the main part may have a cytoplasmic location.
\end{abstract}

\section{INTRODUCTION}

Bordetella pertussis produces at least three distinct toxins (reviewed by Wardlaw and Parton, 1982): the intracellular, heat-labile $\left(56^{\circ} \mathrm{C}, 10 \mathrm{~min}\right)$ dermonecrotising toxin (HLT), the lipopolysaccharide (LPS) endotoxin, and a substance variously designated as pertussigen, pertussis toxin, islets-activating protein, histamine-sensitising factor (HSF) and leukocytosis-promoting factor (LPF). In recent years both LPS and pertussigen have been extensively purified and characterised.

By contrast, the HLT has been comparatively neglected although it was the first of the B. pertussis toxins to be reported (Bordet and Gengou, 1909). Only one group of investigators (Nakase et al., 1969) claims to have obtained HLT as a homogeneous

Received 20 Jun. 1983; accepted 28 Jul. 1983.

* Present address: Department of Microbiology, University of Leeds, Leeds LS2 9JT. 
protein but this work has not yet been confirmed elsewhere. The mechanism of action of HLT is unknown. It is dermonecrotising and lethal in mice, guinea pigs and rabbits, and, after intravenous injection, causes splenic atrophy (Iida and Okonogi, 1971). The haemorrhagic, dermonecrotising response of suckling mice provides the most sensitive assay (Gardner, cited by Pittman, 1970). The possible involvement of HLT in the pathogenesis of pertussis is obscure. Evidence against a significant role is suggested by the absence of anti-HLT in pertussis convalescent sera (Evans and Maitland, 1939; Evans, 1947), the lack of protective activity of toxoided HLT in the intracerebral mouse protection test (Nakase et al., 1969) and the deliberate destruction of HLT during the routine preparation of pertussis vaccine. On the other hand, the apparently invariable presence of HLT in freshly isolated strains of all three species of Bordetella indicates a degree of evolutionary conservation that would be consistent with the toxin having some essential role in the host-parasite interaction.

So far there has been little systematic and quantitative study of the production of HLT by different strains of $B$. pertussis in different cultural conditions. The prime aim of the present work was to rectify this deficiency. This report also presents data on the storage stability of HLT, its partial purification, mol. wt by gel filtration, kinetics of inactivation by formaldehyde and its immunogenicity in mice and rabbits.

\section{MATERIALS AND METHODS}

Strains. The following strains of $B$. pertussis were used: 18334 , a vaccine strain, was obtained from Connaught Laboratories Ltd, Canada; 134 was used by Pillemer (1950) in the preparation of his protective antigen adsorbed on to human red cell stromata; strain Maeno was supplied by Professor Y. Nakase, Kitasato Institute, 5-9-1 Shirokane, Minato-Ku, Tokyo 108, Japan; 28 was provided by Dr P. Novotny, Wellcome Research Laboratories, Beckenham; B-1593/57 was from Dr V. Spasojević, Institute of Immunobiology and Virology, Torlak, Vojvode Stepe 458, Belgrade, Yugoslavia; 44122/7R, a streptomycin-resistant mutant derived from vaccine strain $44122 / 7$ and used at the State Bacteriological Laboratory, Stockholm, Sweden, was obtained from Dr P. Branefors, University of Göteborg, Institute of Medical Microbiology, Department of Bacteriology, Guldhedsgatan 10, S-413 46 Göteborg, Sweden; 18904-L4, was from Dr P. Kendrick, Michigan Department of Health, Grand Rapids, Michigan, USA; 77/18319 and 77/24833 were obtained as fresh isolates from Dr R. Fallon, Department of Bacteriology, Ruchill Hospital, Glasgow; 3865, D30042-I and D3148-I were supplied by Dr J. Dolby, Clinical Research Centre, Harrow.

Culture media. The following media were used: Bordet-Gengou agar (Gibco Bio-Cult Diagnostics Ltd, Paisley, Scotland), Charcoal agar base (Difco Laboratories, Detroit 1, Michigan, USA) without the addition of blood, modified Hornibrook medium (Wardlaw, Parton and Hooker, 1976), and Stainer and Schölte (12G) medium as described by Stainer and Schölte (1971) but with one-quarter the amount of Tris buffer. To study the effect of iron concentrations on HLT production, Stainer and Schölte (12G) medium was also prepared with six different concentrations of $\mathrm{FeSO}_{4}$ including the usual formulation. Iron concentrations were assayed with 2,2' bipyridyl by the method of Herbert, Phipps and Strange (1971).

Standardisation of bacterial concentration by opacity. The concentration of cell suspensions was measured in International Opacity Units (o.u.) by standardisation against the WHO international reference preparation of opacity (Perkins et al., 1973).

When a cell suspension was disrupted, the concentration was still described in terms of opacity (i.e., opacity unit equivalents) because the concentration of the lysate was directly equivalent to the cell suspension from which it was derived.

Lethal toxicity titration in weaned mice. Groups of five to $10 \mathrm{HAM} / 1 \mathrm{CR}$ mice (Charles River, UK, Ltd), 3-4 weeks old, were given intraperitoneal injections of $0 \cdot 5-\mathrm{ml}$ volumes of 
graded doses of $B$. pertussis samples. The animals were arranged to give similar weight distributions in each group. Deaths were recorded 3 days after injection and the results evaluated by the probit method using a computer programme.

Toxicity titration in suckling mice. Four-day-old HAM/1 CR mice (Charles River, U.K. $\mathrm{Ltd}$ ) were given subcutaneous injections in the back of the neck of $0.05-\mathrm{ml}$ volumes of graded doses of $B$. pertussis samples and returned to their litters. Twenty-four hours later, deaths were recorded and haemorrhagic reactions were scored on a $1+$ to $4+$ scale.

Protein estimation. The method of Herbert et al. (1971) was used.

Preparative gel filtration was done with the same gel, buffer and temperature as described below but in a column of dimensions $2.6 \times 40 \mathrm{~cm}$, with samples of $2.5 \mathrm{ml}$ (protein $20-30 \mathrm{mg} / \mathrm{ml}$ ) and a flow rate of $3 \mathrm{ml} / \mathrm{cm}^{2} / \mathrm{h}^{1} ; 3-\mathrm{ml}$ fractions were collected.

Molecular weight by gel filtration. A column $(1.5 \times 84 \mathrm{~cm})$ of Ultrogel AcA 44 (LKB-Produkter $\mathrm{AB}$, Sweden) was equilibrated at $4 \mathrm{C}$ with $0 \cdot 15 \mathrm{~m}$ potassium phosphate buffer $p \mathrm{H} 7 \cdot 4$. The void volume ( $\mathrm{Vo}$ ) was determined from the elution position of blue dextran $2000(3.75 \mathrm{mg}$ in 0.75 $\mathrm{ml}$ of buffer; Pharmacia Fine Chemicals Ltd, Uppsala, Sweden), and the elution volumes (Ve) for three standard proteins (Sigma Chemical Company Ltd, St Louis, MO, USA) of known mol. wt were found; the proteins were lysozyme (grade l reagent, mol. wt 14400 ), ovalbumin (grade V reagent mol. wt 44000 ) and human serum albumin (fraction V, mol. wt 66500$)$. Samples $(0.75$ $\mathrm{ml}$ of $5 \mathrm{mg}$ protein $/ \mathrm{ml}$ buffer) were run individually. For each standard protein the ratio of elution volume $(\mathrm{Ve})$ to void volume $(\mathrm{Vo})$ was calculated and plotted against the logarithm of the mol. wt. The toxin preparation, a $B$. pertussis lysate supernatant fluid fractionally precipitated with ammonium sulphate (30-50\% saturation), was applied to the calibrated column. As before, a $0.75-\mathrm{ml} \mathrm{sample} \mathrm{was} \mathrm{used} \mathrm{(protein} 25 \mathrm{mg} / \mathrm{ml}$ ), with a flow rate of $2.5 \mathrm{ml} / \mathrm{cm}^{2} / \mathrm{h}^{1}$, and $1-\mathrm{ml}$ fractions were collected. From the ratio of $\mathrm{Ve} / \mathrm{Vo}$ for the toxin, a mol. wt value was obtained from the standard curve.

The elution of samples was monitored spectroscopically at $280 \mathrm{~nm}$ for protein samples and $620 \mathrm{~nm}$ for blue dextran. The position of HLT was established by testing samples for their haemorrhagic activity in suckling mice.

Detoxification of HLT; the effect of temperature and formaldehyde. Cells of B. pertussis strain 134 were disrupted in an X-press (LKB Instruments Ltd, South Croydon, Surrey), centrifuged at $100000 \mathrm{~g}$ for $1 \mathrm{~h} \mathrm{at} 4^{\circ} \mathrm{C}$ and the supernatant fluid sterilised by passage through a $0.22 \mu \mathrm{m}$ membrane filter (Millipore SA, Molsheim, France). This preparation (65 LD50/ml, protein $2 \mathrm{mg} / \mathrm{ml}$ ) was held at either $4^{\circ} \mathrm{C}$ or $37^{\circ} \mathrm{C}$ with or without the addition of $2.5 \%(\mathrm{v} / \mathrm{v})$ formalin (BDH, Poole, England) to a final concentration of $0.25 \%(\mathrm{v} / \mathrm{v})$. At various times throughout the 14-day test period, samples were taken, dialysed overnight at $4^{\circ} \mathrm{C}$ against phosphate buffered saline to remove formaldehyde (where present), then stored at $-20^{\circ} \mathrm{C}$ for subsequent toxicity testing. Precautions were taken to ensure bacteriological sterility.

Immunisation of mice and rabbits with formaldehyde-detoxified HLT. A crude preparation of HLT, a B. pertussis strain 134 lysate supernatant fluid (final concentration protein $2 \mathrm{mg} / \mathrm{ml}$ ), was detoxified by incubation for 15 days at $4{ }^{\circ} \mathrm{C}$ with $0.25 \%(\mathrm{v} / \mathrm{v})$ formalin, after which the formaldehyde was removed by dialysis. Groups of 3-4 week old HAM/1 CR mice were immunised with this material with or without an adjuvant $\left(\mathrm{A} 1(\mathrm{OH})_{3}\right.$, or Freund's incomplete or complete adjuvant), in a course of one to three injections given intraperitoneally, subcutaneously or intramuscularly. The most intensively immunised animals received in three doses over a 4-week period, 14 mouse LD50 equivalents of toxin or $250 \mu \mathrm{g}$ of protein. To test for the development of antitoxic immunity, mice were, $2-3$ weeks after the final injection, either bled for sera or challenged with 3 LD50 of HLT. Four New Zealand White rabbits were immunised with the same batch of toxoid that was given to the mice. Two rabbits received 560 mouse LD50 equivalents of toxoid or $10 \mathrm{mg}$ of protein, and two others were given 900 mouse LD50 equivalents or $16.3 \mathrm{mg}$ of protein. The first of the four injections of toxoid to each animal was given intramuscularly in Freund's complete adjuvant and the remainder intraperitoneally in Freund's incomplete adjuvant at 4-week intervals. The animals were bled 2 weeks after the last injection.

Titration of anti-HLT. Sera were assayed for anti-HLT by mixing equal volumes of each dilution with a dose of toxin chosen to give a $1+$ haemorrhagic reaction in a suckling mouse in the absence of neutralisation. Mixtures were held at $20^{\circ} \mathrm{C}$ for $2 \mathrm{~h}$ and injected into suckling mice 
which were followed up as described earlier. One unit of antitoxin was taken as the smallest amount of antiserum that neutralised one $1+$ dose of toxin.

Absorption of antisera with B. pertussis. Freshly-harvested cells of B. pertussis strain $134(1 \mathrm{~g}$ wet weight) were mixed with $10 \mathrm{ml}$ of heated $\left(56^{\circ} \mathrm{C}, 10 \mathrm{~min}\right)$ rabbit antiserum and left at $20^{\circ} \mathrm{C}$ for $1 \mathrm{~h}$. After centrifugation at $15000 \mathrm{~g}$ for $20 \mathrm{~min}$ at $20^{\circ} \mathrm{C}$, the supernate was decanted and exposed to three or four further cycles of absorption with the same amount of bacteria and by the same procedure. The absorbed sera were rendered free from residual B. pertussis cells by membrane filtration. Agglutinin titres of $600-800$ in the unabsorbed serum were reduced to below one by the absorption process.

\section{RESULTS}

\section{Factors influencing HLT production}

Comparison of different strains. It was considered likely that $B$. pertussis strains might vary considerably in their content of HLT; therefore, a set of 12 strains was examined. These included fresh isolates, vaccine strains and strains from Professor $Y$. Nakase and Drs P. Kendrick, P. Novotny, and V. Spasojević, sent in response to our request for the "most toxic $B$. pertussis strain in your culture collection". Each strain was grown for $48 \mathrm{~h}$ on Bordet-Gengou agar, harvested in phosphate buffered saline, standardised in opacity, and stored frozen $\left(-20^{\circ} \mathrm{C}\right)$ until assayed for mouse-lethal toxicity in comparison with strain 18334 which was taken as the reference standard. Table I shows that the strains, when compared on an equal opacity basis, were remarkably homogeneous in their mouse toxicity; the range in relative potencies between the highest and the lowest was only about three-fold. Only two strains (28 and Maeno) were significantly more potent than strain 18334 , but even here the difference was slight.

The three most toxic strains (134, 28 and Maeno) were retested several times and confirmation obtained that each was usually between two and three times as toxic as strain 18334, but that there were no significant differences within the group of three. Most of the subsequent work was done with strain 134; strain 18334 was retained as a reference.

\section{TABLE I}

Mouse-lethal toxicity of 11 B. pertussis strains relative to strain 18334 (tested as frozen and thawed suspensions of cells grown on Bordet-Gengou agar)

\begin{tabular}{l|cc}
\hline & $\begin{array}{c}\text { Relative toxicity } \\
\text { Strain no. }\end{array}$ & \\
(strain $18334=1 \cdot 0)$ & $(95 \%$ & confidence limits) \\
\hline D30042-I & 0.9 & $(0 \cdot 3-2 \cdot 2)$ \\
3865 & 0.9 & $(0 \cdot 3-2 \cdot 2)$ \\
134 & $2 \cdot 4$ & $(0 \cdot 9-6 \cdot 7)$ \\
D3148-I & 1.4 & $(0 \cdot 8-2 \cdot 4)$ \\
28 & $2 \cdot 6$ & $(1 \cdot 5-4 \cdot 6)$ \\
Maeno & $2 \cdot 0$ & $(1 \cdot 2-3 \cdot 6)$ \\
$77 / 18319$ & $1 \cdot 2$ & $(0 \cdot 6-2 \cdot 4)$ \\
$77 / 24833$ & $0 \cdot 8 *$ & $\ldots$ \\
$18904-L 4$ & $1 \cdot 1 *$ & $(0 \cdot 5-1 \cdot 7)$ \\
B-1593/57 & $1 \cdot 0$ & $(1 \cdot 0-2 \cdot 6)$ \\
$44122 / 7 \mathrm{R}$ & 1.6 & \\
\hline
\end{tabular}

* Approximate values; confidence limits not calculated because of assay invalidity. 
TABLE II

Mouse-lethal toxicity of three strains of B. pertussis, tested as suspensions of frozen and thawed whole cells, grown on four different culture media and harvested after $24 \mathrm{~h}$ and $72 \mathrm{~h}$

\begin{tabular}{|c|c|c|c|c|}
\hline \multirow[b]{2}{*}{ Strain no. } & \multirow[b]{2}{*}{$\begin{array}{l}\text { Age of culture } \\
\text { (h) }\end{array}$} & \multicolumn{3}{|c|}{$\begin{array}{c}\text { Relative toxicity* }(95 \% \text { confidence limits) } \\
\text { of cultures grown on or in }\end{array}$} \\
\hline & & Charcoal agar & $\begin{array}{l}\text { Modified Hornibrook } \\
\text { liquid medium }\end{array}$ & $\begin{array}{l}\text { Stainer and Schölte } \\
\text { (12G) liquid medium }\end{array}$ \\
\hline 18334 & $\begin{array}{l}24 \\
72\end{array}$ & $\begin{array}{l}1.0(0.4-2.5) \\
1.0+\end{array}$ & $\begin{array}{l}0.7(0.3-1.8) \\
1.6(0.6-4.4)\end{array}$ & $\begin{array}{l}1.7(0.7-4 \cdot 1) \\
2.3(0.8-6.3)\end{array}$ \\
\hline \multirow[t]{2}{*}{134} & 24 & $1.6(0.8-3.3)$ & $1.4(0.7-2.9)$ & $0.9(0.4-1.8)$ \\
\hline & 72 & $1.3+\ldots$ & $2 \cdot 7(1 \cdot 5-6 \cdot 0)$ & $1 \cdot 9(1 \cdot 0-4 \cdot 1)$ \\
\hline \multirow[t]{2}{*}{$77 / 18319$} & 24 & $1.5(0.9-3.0)$ & $0.8(0.4-1.6)$ & $0.9(0.4-1.6)$ \\
\hline & 72 & $1 \cdot 2(0 \cdot 6-2 \cdot 4)$ & $1.4(0.7-2.9)$ & $1 \cdot 2(0 \cdot 6-2 \cdot 4)$ \\
\hline
\end{tabular}

* For each strain, cells grown on Bordet-Gengou medium were taken as the reference and only cultures of the same age were compared; values for Bordet-Gengou cultures $=1 \cdot 0$.

$\uparrow$ Approximate value; confidence limits not calculated because of assay invalidity.

\section{TABLE III}

Mouse-lethal toxicity of three strains of B. pertussis harvested after growth for $24 \mathrm{~h}$ and $72 \mathrm{~h}$ on various media and tested as suspensions of frozen and thawed whole cells

\begin{tabular}{l|cccc}
\hline & \multicolumn{4}{|c}{ Relative toxicity* $(95 \%$ confidence limits $)$ of cultures grown on or in } \\
\cline { 2 - 5 } Strain no. & $\begin{array}{c}\text { Bordet-Gengou } \\
\text { agar }\end{array}$ & $\begin{array}{c}\text { Charcoal } \\
\text { agar }\end{array}$ & $\begin{array}{c}\text { Modified Hornibrook } \\
\text { liquid medium }\end{array}$ & $\begin{array}{c}\text { Stainer and Schölte } \\
(12 \mathrm{G}) \text { liquid medium }\end{array}$ \\
\hline 18334 & $0 \cdot 6(0 \cdot 2-7 \cdot 1)$ & $0 \cdot 6(0 \cdot 2-7 \cdot 1)$ & $1 \cdot 7(0 \cdot 5-6 \cdot 7)$ & $1 \cdot 0(0 \cdot 1-10 \cdot 9)$ \\
134 & $0 \cdot 6(0 \cdot 2-1 \cdot 4)$ & $0 \cdot 6(0 \cdot 3-1 \cdot 0)$ & $1 \cdot 3(0 \cdot 6-3 \cdot 0)$ & $1 \cdot 3(0 \cdot 8-2 \cdot 3)$ \\
$77 / 18319$ & $1 \cdot 2(0 \cdot 6-2 \cdot 9)$ & $0 \cdot 9(0 \cdot 4-1 \cdot 8)$ & $1 \cdot 9(1 \cdot 0-5 \cdot 7)$ & $1 \cdot 7(0 \cdot 8-8 \cdot 3)$
\end{tabular}

* Toxicity of 72-h culture relative to toxicity of 24-h culture of the same strain on the same medium when value for 24 -h culture $=1 \cdot 0$.

Culture medium and time of harvest. Because there is little published information on the effect of culture medium and time of harvest on HLT production by B. pertussis, a study of these factors was made on three representative strains, using four media, with cells harvested at $24 \mathrm{~h}$ and $72 \mathrm{~h}$. The results in table II show that neither composition nor solid-liquid state of medium exerted any major influence on the HLT content in any of the three strains examined (134, 18334 and 77/18319). However, the time of harvesting did seem to influence the toxicity of the cells. Overall, with the solid media, 24-h cultures were marginally more toxic than $72-\mathrm{h}$ cultures whereas in liquid media the converse held (table III), though the differences were not significant. Only with the 72-h samples from cultures of strains 18334 and 134 grown in modified Hornibrook medium was any HLT detected in the culture supernatant fluid and even then only at low concentrations.

Iron content of medium. From table IV it is apparent that concentrations of iron in the range $0.03-6.3 \mathrm{mg} / \mathrm{L}$ did not much influence $\mathrm{HLT}$ production by strain 134 in Stainer and Schölte (12G) medium. None of the experimental media gave yields of toxin significantly different from normal Stainer and Schölte $(12 \mathrm{G})$ medium (iron $2 \cdot 1$ 
TABLE IV

Effect of the iron content of Stainer and Schölte ( $12 G)$ medium on toxin production by B. pertussis strain 134 (mouse-lethal toxicity assayed using suspensions of frozen and thawed whole cells)

\begin{tabular}{c|ccc}
\hline $\begin{array}{c}\text { Added iron } \\
(\mathrm{mg} / \mathrm{L})\end{array}$ & $\begin{array}{c}\text { Measured iron } \\
(\mathrm{mg} / \mathrm{L}) \\
\text { in medium }\end{array}$ & Relative toxicity* & $(95 \%$ confidence limits) \\
\hline 6.30 & $\ldots$ & 1.0 & $(0 \cdot 4-2 \cdot 6)$ \\
2.10 & 1.80 & $1 \cdot 0$ & $\ldots$ \\
0.70 & 0.63 & 0.4 & $(0 \cdot 1-1 \cdot 1)$ \\
0.23 & 0.21 & 0.7 & $(0 \cdot 3-1 \cdot 9)$ \\
0.08 & 0.16 & 1.0 & $(0 \cdot 4-2 \cdot 6)$ \\
0.00 & 0.03 & 1.4 & $(0 \cdot 5-3 \cdot 5)$ \\
\hline
\end{tabular}

*Value obtained with culture grown in medium with iron $2 \cdot 1 \mathrm{mg} / \mathrm{L}=1 \cdot 0$.

$\mathrm{mg} / \mathrm{L}$ ). Furthermore, none of the culture supernates were toxic except for the one from the medium with the highest iron content which was slightly toxic.

High nicotinic acid concentration. None of the above studies had revealed any strain or cultural condition that gave unusually high levels of HLT. Therefore, tests were made to see if HLT production could be inhibited deliberately. Already it has been shown that growth under $\mathrm{C}$-mode conditions (high magnesium sulphate) yields cells with much reduced HLT (Livey, Parton and Wardlaw, 1978) and causes the loss of cell-envelope components (Wardlaw et al., 1976). However, B. pertussis strains are reported to retain their full toxicity when grown in media with high concentrations of nicotinic acid, another known modulating agent (Pusztai and Joó, 1967). To resolve this possible anomaly, strain 134 was grown on Bordet-Gengou agar and charcoal agar with and without added nicotinic acid $500 \mu \mathrm{g} / \mathrm{ml}$. Growth on the media supplemented with nicotinic acid resulted in a significant reduction in the toxicity of the cells of about $60 \%$ (table V). The loss of the $28 \mathrm{~K}$ and $30 \mathrm{~K}$ cell-envelope polypeptides, and at least in

TABLE V

Effect of nicotinic acid growth-supplement on the mouse-lethal toxicity of cells of B. pertussis strain 134 (tested as frozen and thawed suspensions of whole cells)

\begin{tabular}{|c|c|c|c|c|c|c|}
\hline \multirow[b]{2}{*}{ Medium } & & \multicolumn{3}{|c|}{$\begin{array}{l}\text { Number of deaths/ } \\
\text { number of mice } \\
\text { treated with suspensions } \\
\text { prepared from the given } \\
\text { medium in doses* of }\end{array}$} & \multirow{2}{*}{$\begin{array}{l}\text { Relative } \\
\text { toxicity } \dagger\end{array}$} & \multirow{2}{*}{$\begin{array}{l}(95 \% \\
\text { confidence } \\
\text { limits })\end{array}$} \\
\hline & & 5 & $2 \cdot 5$ & $1 \cdot 25$ & & \\
\hline $\begin{array}{l}\text { Bordet-Gengou } \\
\text { agar }\end{array}$ & $\left\{\begin{array}{l}\text { unmodified } \\
\text { with nicotinic } \\
\text { acid }+\end{array}\right.$ & $\begin{array}{l}5 / 5 \\
5 / 5\end{array}$ & $\begin{array}{l}5 / 5 \\
0 / 5\end{array}$ & $\begin{array}{l}2 / 5 \\
0 / 5\end{array}$ & $\begin{array}{l}1 \cdot 0 \\
0 \cdot 37\end{array}$ & $(0.23-0.60)$ \\
\hline $\begin{array}{l}\text { Charcoal } \\
\text { agar }\end{array}$ & $\left\{\begin{array}{l}\text { unmodified } \\
\text { with nicotinic } \\
\text { acid }{ }^{\dagger}\end{array}\right.$ & $\begin{array}{l}4 / 5 \\
3 / 5\end{array}$ & $\begin{array}{l}5 / 5 \\
0 / 5\end{array}$ & $\begin{array}{l}0 / 5 \\
0 / 5\end{array}$ & $\begin{array}{l}1 \cdot 0 \\
0 \cdot 44\end{array}$ & $(0 \cdot 19-0.79)$ \\
\hline
\end{tabular}

\footnotetext{
* Doses measured as opacity units (o.u.) $/ 0.5 \mathrm{ml}$ of suspension injected.

$\uparrow$ Toxicity of cells grown on nicotinic acid supplemented media relative to toxicity of those grown on the equivalent unmodified medium.

$\ddagger$ Nicotinic acid $500 \mu \mathrm{g} / \mathrm{ml}$.
} 
the Bordet-Gengou-grown cells the loss of HSF, verified that those cell-envelope changes associated with growth in media with a high nicotinic acid content had also occurred (Wardlaw et al., 1976).

\section{Storage stability of $H L T$}

Four samples of cell-lysates of strain 18334 were assayed for their mouse-lethal toxicity throughout 3 years of storage at $-20^{\circ} \mathrm{C}$. The results in fig. 1 show that superimposed on the considerable scatter in successive assays due to unavoidable variations in mouse sensitivity, there was an average loss of about $10 \%$ of the potency per annum. Further information on storage stability at $4^{\circ} \mathrm{C}$ and $37^{\circ} \mathrm{C}$ is given in the section on the effect of temperature and formaldehyde on HLT activity.

\section{Partial purification of $H L T$}

Although several methods have been described for the purification of HLT, none has received independent confirmation of feasibility and yield, and thereby become established as suitable for routine use. Our attempts to apply the method of Nakase $e t$ al. (1969) gave only very low yields of still impure material. Therefore, a careful study was made of the stability and yield of HLT during certain physicochemical manipulations which were explored as potential stages in a new purification scheme.

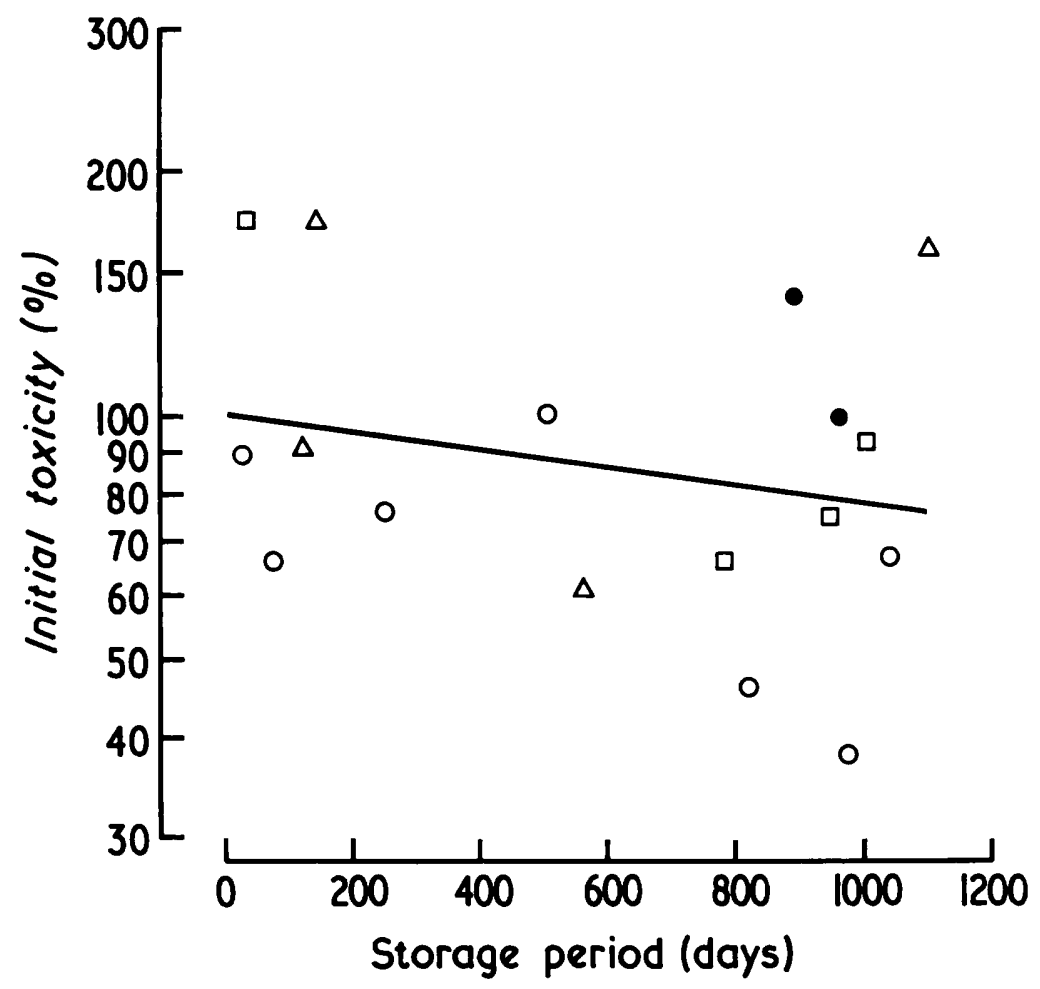

FIG. 1. - Loss of mouse-lethal toxicity in four samples of $B$. pertussis cell-lysate $(O, \Delta, \square, \bullet)$ during storage at $-20^{\circ} \mathrm{C}$ for up to 3 years. 
Disruption of $B$. pertussis and release of HLT. HLT has an intracellular location and it is necessary to disrupt the bacteria to release the toxin in soluble form. Freshly harvested cells were lysed by three passages through an X-press. This gave a significant increase in toxicity $(\mathrm{P}<0.05)$ compared with the intact bacteria. In four separate determinations, lysates were 4-14 times more toxic than the cell suspensions from which they were derived, an observation made by previous investigators (Evans and Maitland, 1937; Smolens and Flavell, 1947; Cowell, Hewlett and Manclark, 1979).

Preparative ultracentrifugation. Ultracentrifugation $\left(100000 \mathrm{~g}, 1 \mathrm{~h}, 4^{\circ} \mathrm{C}\right)$ was introduced to remove insoluble material from lysates. The data from four different lysates showed that, on average, $71 \%$ of the HLT was recovered in the supernatant fluid (table VI). As only about $38 \%$ of the total protein was found in this soluble fraction, the ultracentrifugation step provided a two-fold purification.

\section{TABLE VI}

Distribution of HLT and protein between the supernatant fluid and pellet after ultracentrifugation of $B$. pertussis cell-lysates

\begin{tabular}{|c|c|c|c|}
\hline \multirow{2}{*}{$\begin{array}{c}\text { Experiment } \\
\text { no. }\end{array}$} & \multicolumn{2}{|c|}{$\begin{array}{c}\text { Relative toxicity* } \\
(95 \% \text { confidence limits }) \\
\text { of }\end{array}$} & \multirow{2}{*}{$\begin{array}{l}\text { Percentage of cell-lysate protein } \\
\text { in the supernate }\end{array}$} \\
\hline & Supernate & Pellet & \\
\hline $\begin{array}{l}1 \dagger \\
2 \\
3 \\
4 \dagger\end{array}$ & $\begin{array}{l}42(24-74) \\
70(36-131) \\
83(50-135) \\
89(63-125)\end{array}$ & $\begin{array}{l}22(13-38) \\
20(9-38) \\
24(13-39) \\
34(24-50)\end{array}$ & $\begin{array}{l}33 \\
43 \\
37 \\
\cdots\end{array}$ \\
\hline Average & 71 & 25 & 38 \\
\hline
\end{tabular}

Fractionation with ammonium sulphate. After incubation for $15 \mathrm{~min}$ at $30^{\circ} \mathrm{C}$ with DNAase 1 and RNAase A (Sigma Chemical Company Ltd, St Louis, MO, USA), each at $50 \mu \mathrm{g} / \mathrm{ml}$, to reduce the viscosity due to nucleic acids, lysate supernatant fluids were fractionally precipitated at $4{ }^{\circ} \mathrm{C}$ with ammonium sulphate (table VII). In the $30-50 \%$ precipitate, $70 \%$ of the HLT was recovered but only $47 \%$ of the protein (a $1 \cdot 5$-fold purification).

TABLE VII

Distribution of HLT and protein after ammonium sulphate fractionation of a DNAase- and RNAase-treated lysate supernate

\begin{tabular}{l|ccc}
\hline \multicolumn{1}{c|}{ Fraction $\dagger$} & Relative toxicity* & $(95 \%$ confidence limits $)$ & Protein* content \\
\hline $30 \%$ precipitate & 11 & $(7-18)$ & 10 \\
$30-50 \%$ precipitate & 70 & $(44-117)$ & 47 \\
$50-70 \%$ precipitate & $<2$ & $\ldots$ & 24 \\
$70 \%$ supernatant fluid & $<3$ & $\ldots$ & 16 \\
\hline
\end{tabular}

* Value for DNAase- and RNAase-treated lysate supernate $=100$.

$\dagger$ Percentage figures based on percentage saturation with $\left(\mathrm{NH}_{4}\right)_{2} \mathrm{SO}_{4}$ at $0^{\circ} \mathrm{C}$ (Dixon, 1953). 


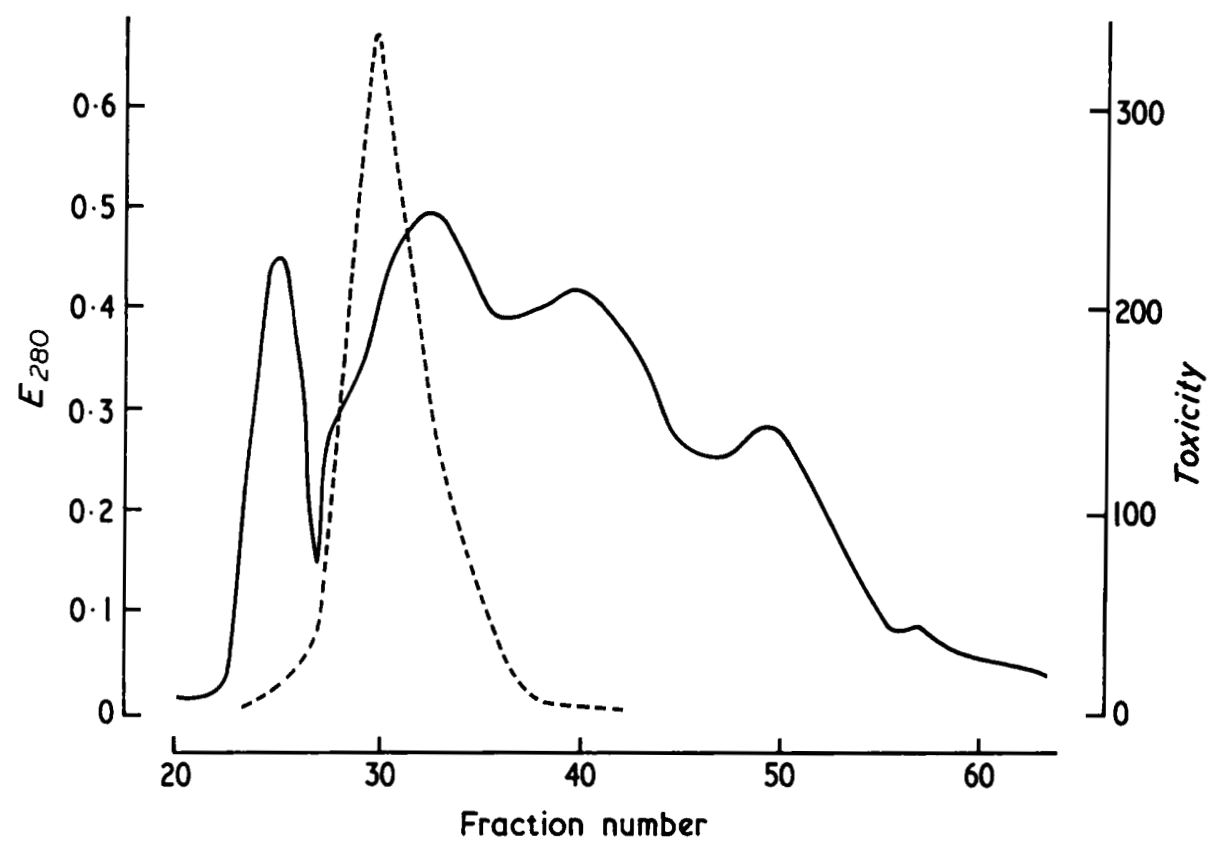

FIG. 2.-Elution profile for ammonium sulphate $30-50 \%$ precipitates of crude $B$. pertussis HLT fractionated on Ultrogel AcA $44 ;-=$ extinction at $280 \mathrm{~nm} ;-\cdots=$ toxicity in suckling mice measured as the dilution that gave a $2+$ haemorrhagic response.

Gel filtration of the $30-50 \%$ ammonium sulphate precipitate on Ultrogel AcA 44 yielded four major peaks; HLT was eluted as a single peak on the front shoulder of the second and largest protein peak (fig. 2). By careful selection of the fractions to be pooled, a four-to-five-fold purification was achieved $(34 \%$ recovery of HLT and $7-8 \%$ of the protein). It was also possible to estimate that HLT has a mol. wt of $89000 \pm 10 \%$.

Application of the above methods, in sequence, would be expected, under favourable conditions, to give a 15 -fold purification of HLT in terms of protein, at an overall yield of $20 \%$.

\section{Detoxification of HLT: the effect of temperature and formaldehyde}

HLT has been toxoided by incubation at $37^{\circ} \mathrm{C}$ with formalin $0.25 \%(\mathrm{v} / \mathrm{v})$; in these conditions, detoxification is very rapid and is complete within one day (Evans and Maitland, 1937). Because it was suspected that heat-inactivation of the toxin may have had some part to play in the rapidity of this process, and because heated toxin is ineffective for stimulating the production of neutralising antibodies to HLT (Evans, 1942), it seemed prudent to distinguish between temperature-mediated inactivation and detoxification by formaldehyde. The rate of detoxification of HLT was measured at $4^{\circ} \mathrm{C}$ and $37^{\circ} \mathrm{C}$ in the presence and in the absence of formalin $0.25 \%(\mathrm{v} / \mathrm{v})$.

At $4{ }^{\circ} \mathrm{C}$ without formaldehyde there was no appreciable loss of toxicity over the 14-day test period; the samples (original potency $32 \cdot 5 \mathrm{LD} 50 / 0 \cdot 5-\mathrm{ml}$ injection volume) were still toxic after a 10-fold dilution (fig. 3). However, there was a gradual 


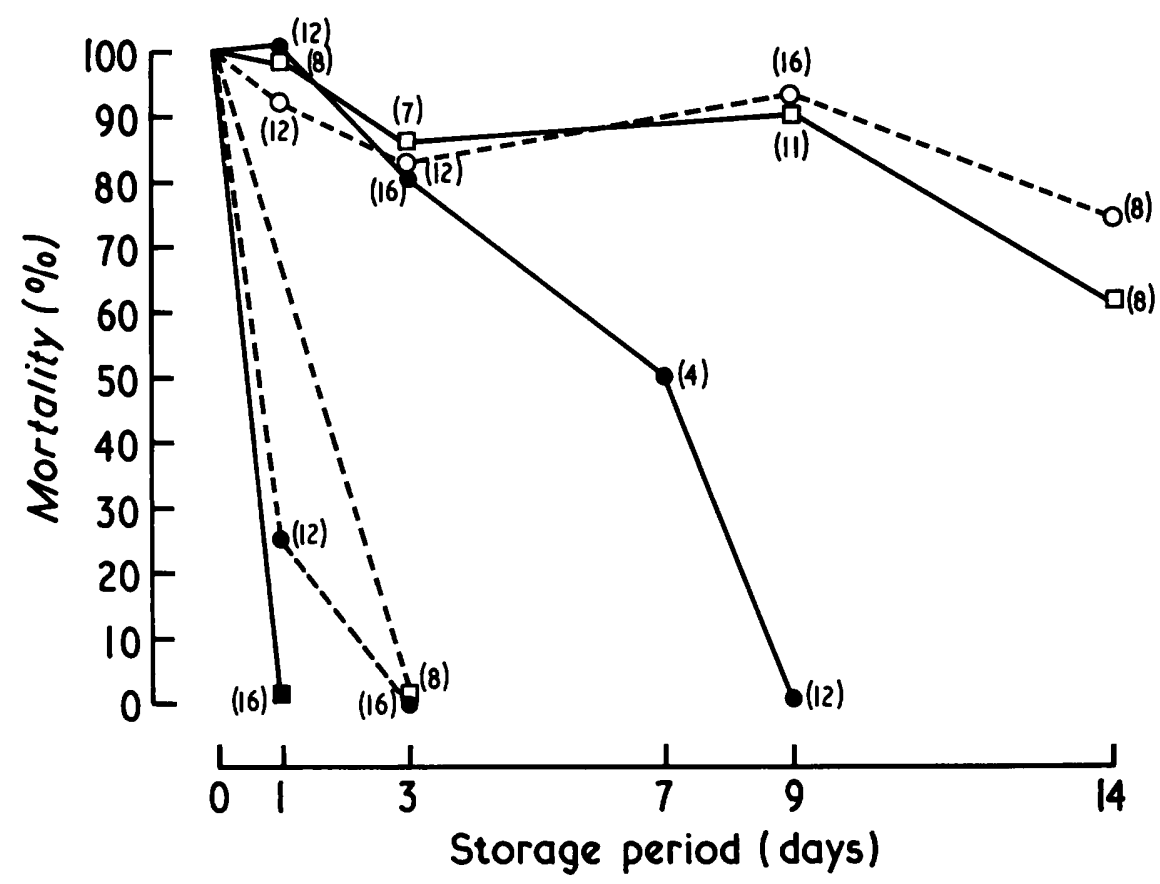

FIG. 3.-Detoxification of HLT by temperature and formaldehyde. Samples of HLT, original potency $32 \cdot 5$ LD $50 / 0.5 \mathrm{ml}$ injection volume, were stored at $4^{\circ} \mathrm{C}(0), 4^{\circ} \mathrm{C}$ with formalin $0.25 \%(\bullet), 37^{\circ} \mathrm{C}(\square)$ and $37^{\circ} \mathrm{C}$ with formalin $0.25 \%(\square)$. Mouse-lethal toxicity was determined for undiluted $(-)$ and ten-fold diluted (- . -) samples. Figures in parentheses show the number of mice tested at each point.

detoxification during storage at $4{ }^{\circ} \mathrm{C}$ with formaldehyde. After one day, $<30 \%$ of the toxicity remained (i.e., the 10 -fold diluted toxin contained $<1 \mathrm{LD} 50 / 0.5 \mathrm{ml}$, cf. 3 LD $50 / 0.5 \mathrm{ml}$ of the original preparation); by day 7 only about $3 \%$ of the toxic activity persisted (i.e., undiluted toxin had a potency of $1 \mathrm{LD} 50 / 0.5 \mathrm{ml}$, cf. $32.5 \mathrm{LD} 50 / 0.5 \mathrm{ml}$ of the original preparation); and by day 9 all toxicity was lost. At $37^{\circ} \mathrm{C}$ detoxification with formaldehyde was very rapid; all activity was destroyed within one day. The control sample held at $37^{\circ} \mathrm{C}$ without added formaldehyde showed a different pattern of loss: although samples were not toxic by day 3 when 10 -fold dilutions were tested, undiluted samples still had residual toxicity at day 14 . Unfortunately, it was not established whether this remaining toxicity was attributable to HLT $\left(56^{\circ} \mathrm{C}\right.$ labile and dermonecrotic) or one of the other toxins.

\section{Immunogenicity of formaldehyde-detoxified HLT in mice and rabbits}

In mice there was total failure to raise anti-HLT neutralising antibodies in spite of using a variety of immunisation conditions, viz., the use of adjuvants (Freund's complete and incomplete, $\mathrm{Al}(\mathrm{OH})_{3}$ ), injection routes (intraperitoneal, subcutaneous, intramuscular) and number of injections (one, two or three). The mice did, however, respond to other antigens as shown by the formation of precipitins demonstrable by immunodiffusion. Consequently the same "toxoid" used with the mice was given to rabbits, a species known to be capable of producing HLT antitoxin. Three rabbits 
responded with mean HLT neutralising titres of 1000,120 and 100 units $/ \mathrm{ml}$ but antiserum from the fourth animal lacked detectable antitoxic activity.

\section{Absorption of anti-HLT sera with B. pertussis cells}

Despite the supposed cytoplasmic location of HLT, repeated absorption of anti-HLT sera with live $B$. pertussis cells removed a substantial proportion of the HLT-neutralising antibodies. One antiserum (1000 units of antitoxin/ml) lost $75 \%$ of its antitoxic activity, and another (100 units of antitoxin $/ \mathrm{ml}$ ) actually became toxic, as shown by haemorrhagic necrosis in suckling mice.

\section{Discussion}

Although B. pertussis has at least three recognised toxins, by far the major part of the mouse-lethal toxicity in freshly-harvested cells is due to HLT. This is demonstrated by the extensive loss of toxicity which occurs during heating at $56^{\circ} \mathrm{C}$ whereas the other two toxins, pertussigen and endotoxin, are respectively labile at $80^{\circ} \mathrm{C}(30$ $\min$ ) and stable at $100^{\circ} \mathrm{C}$. In this investigation, reliance was therefore placed on mouse-lethal toxicity as a convenient first screen for the HLT content of cells and fractions; the haemorrhagic necrosis assay in suckling mice was reserved for occasions when extra sensitivity or specificity was needed. The two tests always yielded concordant results when run in parallel, showing that the lethal-toxicity test was not significantly affected by contributions from the two other toxins.

Attempts to secure a uniquely active HLT-producing strain of $B$. pertussis were unsuccessful. None of the fresh isolates, standard vaccine strains, nor "highly" toxic strains from the culture collections of other investigators proved to be outstanding in this respect. All the strains produced HLT and although there were significant differences in toxin content, these differences were small-of the order of three-fold between the most and least active HLT-producers. The possibility that a more extensive screen might identify a much more potent HLT-producing strain seems remote. Included in the strains examined here was strain B-1593/57, the most toxic of 201 strains screened by Spasojević (1977).

Likewise the HLT content of the bacteria was hardly influenced by changes in culture medium and only slightly by the time of harvest. Perhaps, more frequent sampling during the growth cycle would have revealed slightly larger differences in toxicity than seen here. Cowell et al. (1979) found that cells of B. pertussis strain 114 grown in modified Stainer and Schölte medium were at their most toxic during the mid-log phase of growth, these being up to five times as active as stationary phase cells.

Changing the iron content of the medium did not influence HLT production-at least over the concentration range that markedly influences diphtheria toxin production (Pappenheimer, 1947). On the other hand, a high concentration of nicotinic acid in the medium substantially suppressed the HLT content in cells of $B$. pertussis strain 134 . In this strain at least, HLT production resembles that of pertussigen, the agglutinogens, and the $28 \mathrm{~K}$ and $30 \mathrm{~K}$ envelope polypeptides in being sensitive to modulation by nicotinic acid (Pusztai and Joó, 1967; Wardlaw et al., 1976).

Crude preparations of HLT showed satisfactory storage-stability at $-20^{\circ} \mathrm{C}$; the loss in toxicity was only about $10 \%$ per annum. Even at $4{ }^{\circ} \mathrm{C}$, provided that 
bacteriological sterility was maintained, HLT underwent little appreciable loss of potency during 14 days. At $37^{\circ} \mathrm{C}$, however, the toxin lost most of its potency within a few days. These observations gave confidence that HLT has sufficient stability to withstand such treatments as gel filtration, ammonium sulphate precipitation and dialysis which might be applied as purification procedures and, indeed, this proved to be so. By a combination of ultracentrifugation, treatment with RNAase and DNAase, ammonium sulphate precipitation and gel filtration on Ultrogel AcA 44, it was possible to achieve about a 15 -fold purification over crude cell-lysates at a yield of $20 \%$. The final material was still heterogeneous and was estimated to have about one-quarter of the specific activity of the homogeneous HLT described by Nakase et al. (1969). These authors did not cite the yield of toxin given by their procedure and our attempts to repeat their method were unsuccessful. Our material, on filtration through a calibrated gel column, gave an apparent mol. wt of $89000 \pm 10 \%$, a value which is difficult to reconcile with the value of $1.4 \mathrm{~S}$ reported by Nakase et al. (1969).

When treated with formaldehyde, HLT underwent rapid loss of toxicity at $37^{\circ} \mathrm{C}$ and a slower loss at $4{ }^{\circ} \mathrm{C}$. In each case, controls without formaldehyde were run to separate the effect of temperature from the effect of the chemical. Formaldehydedetoxified material was non-immunogenic in mice, a finding in agreement with earlier reports (Wood, 1940; Anderson and North, 1943; Ospeck and Roberts, 1944), but induced the formation of anti-HLT neutralising antisera in rabbits. When these antisera were absorbed with intact $B$. pertussis cells a significant loss in anti-HLT titre was detected, suggesting that although the primary location of HLT may be the cytoplasm (Cowell et al., 1979), some of it is present on the bacterial surface. Whether or not this association with the cell-surface is fortuitous, resulting from lysis of neighbouring cells, is not clear; but if HLT plays a significant role in the pathogenic activity of the organism, expression would be expected at the cell surface.

We thank Dr Roger Parton for his advice and suggestions throughout this work and in the preparation of this manuscript.

This work was supported by a Medical Research Council grant.

\section{REFERENCES}

Anderson G, North E A 1943 The relation of pertussis endotoxin to pertussis immunity in the mouse. Australian Journal of Experimental Biology and Medical Science 21:1-8.

Bordet J, Gengou O 1909 L'endotoxine coquelucheuse. Annales de l'institut Pasteur 23:41 5-419.

Cowell J L, Hewlett E L, Manclark C R 1979 Intracellular localization of the dermonecrotic toxin of Bordetella pertussis. Infection and Immunity 25:896-901.

Dixon M 1953 A nomogram for ammonium sulphate solutions. Biochemical Journal $54: 457-458$.

Evans D G 1942 Antigenic properties of $H$.pertussis in relation to active immunisation. Lancet 1:529-531.

Evans D G 1947 The failure of whooping cough and adult sera to neutralise pertussis toxin. Journal of Pathology and Bacteriology 59:341-342.

Evans D G, Maitland H B 1937 The preparation of the toxin of $H$.pertussis: its properties and relation to immunity. Journal of Pathology and Bacteriology 45:715-731.

Evans D G, Maitland H B 1939 The toxin of Br. bronchiseptica and the relationship of this organism to $H$. pertussis. Journal of Pathology and Bacteriology 48:67-78.

Herbert D, Phipps P J, Strange R E 1971 Chemical analysis of microbial cells. In: Norris J R, Ribbons D W, (eds) Methods in Microbiology, Vol. 5B. Academic Press, London and New York, pp 209-344. 
Iida T, Okonogi T 1971 Lienotoxicity of Bordetella pertussis in mice. Journal of Medical Microbiology 4:51-61.

Livey I, Parton R, Wardlaw A C 1978 Loss of heat-labile toxin from Bordetella pertussis grown in modified Hornibrook medium. FEMS Microbiology Letters 3:203-205.

Nakase Y, Takatsu K, Tateishi M, Sekiya K, Kasuga T 1969 Heat-labile toxin of Bordetella pertussis purified by preparative acrylamide gel electrophoresis. Japanese Journal of Microbiology 13:359-366.

Ospeck A G, Roberts M E 1944 Pertussis antitoxin: its relationship to protection in actively and passively immunized mice and rabbits. Journal of Infectious Diseases 74:22-31.

Pappenheimer A M 1947 Diphtheria toxin. III. A reinvestigation of the effect of iron on toxin and porphyrin production. Journal of Biological Chemistry 167:251-259.

Perkins F T, Sheffield F W, Outschoorn A S, Hemsley D A 1973 An international collaborative study on the measurement of the opacity of bacterial suspensions. Journal of Biological Standardization 1:1-10.

Pillemer L 1950 Adsorption of protective antigen of Hemophilus pertussis on human red cell stromata. Proceedings of the Society for Experimental Biology and Medicine 75:704-705.

Pittman M 1970 Bordetella pertussis: Bacterial and host factors in the pathogenesis and prevention of whooping cough. In: Mudd S (ed) Infectious agents and host reactions. W B Saunders Co, Philadelphia, pp 239-270.

Pusztai Z, Joó I 1967 Influence of nicotinic acid on the antigenic structure of Bordetella pertussis. Annales Immunologiae Hungaricae 10:63-67.

Smolens J, Flavell E H 1947 The preparation of highly potent endotoxin of Hemophilus pertussis. Journal of Immunology 57:173-177.

Spasojević V. 1977 Study on toxicity of Bordetella pertussis cultures and antigens. Developments in Biological Standardization 34:197-205.

Stainer D W, Scholte M J 1971 A simple chemically defined medium for the production of Phase 1 Bordetella pertussis. Journal of General Microbiology 63:211-220.

Wardlaw A C, Parton R 1982 Bordetella pertussis toxins. Pharmacology and Therapeutics 19:1-53.

Wardlaw A C, Parton R, Hooker M J 1976 Loss of protective antigen, histamine-sensitising factor and envelope polypeptides in cultural variants of Bordetella pertussis. Journal of Medical Microbiology 9:89-100.

Wood M L 1940 A filtrable toxic substance in broth-cultures of $B$. pertussis. Journal of Immunology 39:25-42. 